\title{
Monthly blue water footprint caps in a river basin to achieve sustainable water consumption: The role of reservoirs
}

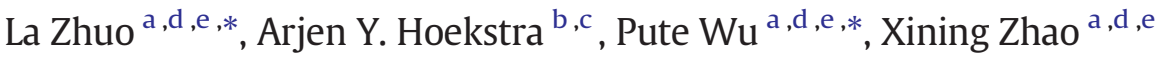 \\ ${ }^{a}$ Institute of Soil and Water Conservation, Northwest AEF University, Yangling 712100, China \\ ${ }^{\mathrm{b}}$ Twente Water Centre, University of Twente, P.O. Box 217, 7500AE Enschede, the Netherlands \\ c Institute of Water Policy, Lee Kuan Yew School of Public Policy, National University of Singapore, 259770, Singapore \\ d Institute of Soil and Water Conservation, Chinese Academy of Sciences and Ministry of Water Resources, Yangling 712100, China \\ e National Engineering Research Centre for Water Saving Irrigation at Yangling, Yangling 712100, China
}

\section{H I G H L I G H T S}

$\overline{\text { - A water footprint cap sets a sustainable }}$ upper limit to human water consumption.

- The effects of reservoirs on water footprint caps and water scarcity are shown.

- The effect of reservoirs on increasing dry-season WF caps is largest in dry years.

- Reservoir storage increases blue water scarcity in wet months.

\section{A R T I C L E I N F O}

\section{Article history:}

Received 30 June 2018

Received in revised form 2 September 2018

Accepted 7 September 2018

Available online 08 September 2018

Editor: R Ludwig

\section{Keywords:}

Sustainable blue water footprint

Reservoir storage

Blue water scarcity

Environmental flow requirement

\section{GRA P H I C A L A B S T R A C T}

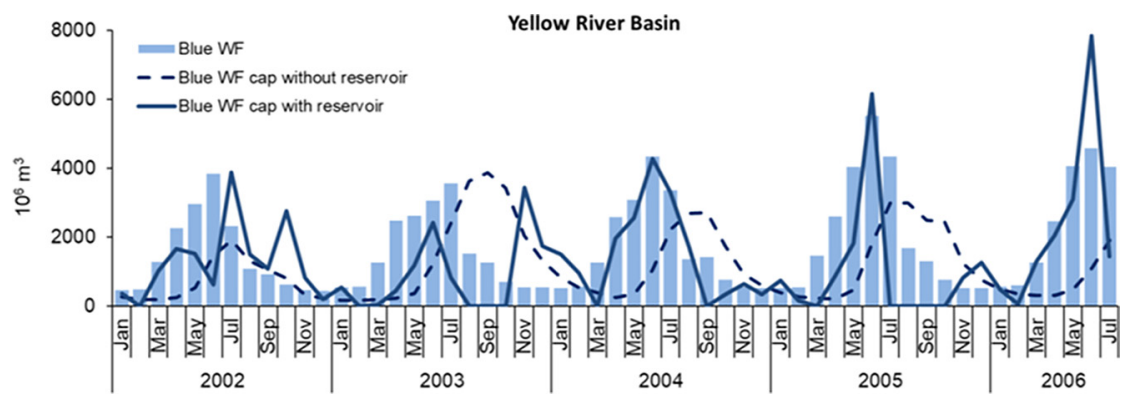

\begin{abstract}
A B S T R A C T
The blue water footprint (WF) measures the consumption of runoff in a river basin. In order to ensure sustainable water consumption, setting a monthly blue WF cap, that is an upper-limit to the blue WF in a river basin each month, can be a suitable policy instrument. The blue WF cap in a river basin depends on the precipitation that becomes runoff and the need to maintain a minimum flow for sustaining ecosystems and livelihoods. Reservoirs along the river generally smooth runoff variability and thus raise the WF cap and reduce blue water scarcity during the dry season. Previous water scarcity studies, considering the ratio of actual blue WF to the blue WF cap under natural background conditions, have not studied this effect of reservoir storages. Here we assess how water reservoirs influence blue WF caps over time and how they affect the variability of blue water scarcity in a river basin. We take the Yellow River Basin over the period January 2002-July 2006 as case study and consider data on observed storage changes in five large reservoirs along the main stream. Results indicate that reservoirs redistribute the blue WF cap and blue water scarcity levels over time. Monthly blue WF caps were generally lowered by reservoir storage during the flood season (July-October) and raised by reservoir releases over the period of highest crop demand (March-June). However, with water storage exceeding $20 \%$ of natural runoff in most rainy months, reservoirs contribute to "scarcity in the wet months", which is to be understood as a situation in which environmental flow requirements related to the occurrence of natural peak flows are no longer met.
\end{abstract}

(C) 2018 Elsevier B.V. All rights reserved.

\footnotetext{
* Corresponding authors at: Institute of Soil and Water Conservation, Northwest A\&F University, Yangling 712100, China.

E-mail addresses: zhuola@nwafu.edu.cn (L. Zhuo), gjzwpt@vip.sina.com (P.Wu).
}

\section{Introduction}

Freshwater consumption in a certain place and time is limited by the available supply. Water availability often hugely fluctuates between dry 
and wet periods of the year and differs across river basins depending on climate (Postel et al., 1996; Oki and Kanae, 2006). Water consumption varies in time and space as well, often countercyclical, with water consumption being highest when water availability is lowest (Hoekstra et al., 2012). Water scarcity, the ratio of water consumption to availability, is thus both river basin and time dependent. It has been estimated that, worldwide, 1.8 to 2.9 billion people live in areas that experience severe water scarcity for at least 4 to 6 months per year, while half a billion people live in places that have severe water scarcity all year round (Mekonnen and Hoekstra, 2016).

From the perspective of sustainability, the blue water footprint (WF) in a river basin, i.e. the consumptive use of the runoff flow, cannot exceed the rate of replenishment, and a substantial part of the natural flow needs to be maintained to support ecosystems and livelihoods. Hoekstra (2013a, 2013b) has proposed that river basin authorities agree on a certain sustainable upper limit to the water consumption. This could be done by formulating a "WF cap" that shows the maximum volume of water consumption specified over time in the year. The blue WF measures water consumption of renewable blue water resources, i.e. the volume of water withdrawn from renewable groundwater and surface water minus the volume of water that is returned (Hoekstra et al., 2011). Practically, the blue WF cap in a river basin can be defined as total natural runoff minus the environmental flow requirement (Hoekstra, 2013a, 2013b). Since both natural runoff and environmental flow requirement vary seasonally, the blue WF cap is also timedependent.

Blue water scarcity in a river basin can be defined on a monthly basis as the ratio of the blue $\mathrm{WF}$ in the month to the maximum sustainable blue WF or the blue WF cap for that month (Hoekstra et al., 2012). There are a few global studies that have quantified blue water scarcity on a monthly basis, either per watershed or river basin (Hoekstra et al., 2012; Brauman et al., 2016; Degefu et al., 2018) or on a 30 arc minute grid level (Wada et al., 2011; Mekonnen and Hoekstra, 2016). There are various monthly water scarcity studies for specific river basins as well: in Morocco (Schyns and Hoekstra, 2014), South Africa (Pahlow et al., 2015), Latin America (Mekonnen et al., 2015) and China (Zeng et al., 2012; Liu et al., 2015; Zhuo et al., 2016). None of the available studies, however, shows the effect of reservoirs on water scarcity mitigation. To some degree, water scarcity in the dry periods of the year can be mitigated by storing water in artificial reservoirs in the wet period and releasing it in the dry period. In the presence of reservoirs, the blue WF cap can thus be raised in dry months. The cap is lowered in the wet months (when water is being stored), but this doesn't need to be a problem as long as there is sufficient water for meeting both human water demands and environmental flow requirements in these months.

Over half of the large river systems on the planet are regulated by human beings. More than 45,000 dams and reservoirs, holding back one seventh of global total annual river runoff, have been constructed to store river water for irrigation, urban water supply, hydroelectricity generation, flood control and smoothing runoff variability (Nilsson et al., 2005; Jaramillo and Destouni, 2015). Most of the reservoirs built in water-abundant river basins are for hydroelectric generation, while the majority of the reservoirs located in water-scarce areas are meant for collecting water in the wet season to secure adequate supply of water for irrigation, households and industries in the dry season (Bakken et al., 2015; Hogeboom et al., 2018). Reservoirs are water consumers themselves: total evaporation from all reservoirs in the world has been estimated to be equivalent to $25 \%$ of global consumptive water use in irrigation and industrial and municipal purposes (Hogeboom et al., 2018; Mekonnen and Hoekstra, 2012). The growth in global storage capacity in large and medium-sized reservoirs has been levelling off in the past century and will be insufficient to satisfy future increasing water demands from expanding populations and economies under different climate change scenarios (Yoshikawa et al., 2014; Veldkamp et al., 2017). Various earlier studies have analysed the effects of reservoir operations on runoff (Vörösmarty et al., 1997; Haddeland et al., 2006; Jaramillo and Destouni, 2015). Hanasaki et al. (2006) simulated global river discharge accounting for 452 reservoirs and found that reservoir operations could alter monthly discharge for individual basins by $>20 \%$. The annual global discharge had decreased by $0.8-2.1 \%$ due to reservoir operations and irrigation extractions, which seems relatively small, but the impacts manifest themselves in specific river basins in the dry periods of the year (Biemans et al., 2011; Döll et al., 2009). All these studies focused on the effects of reservoirs on runoff and have not addressed the next question, i.e. how reservoirs affect the water availability regime over time when accounting for environmental flow requirements (EFRs) and thus how reservoirs could influence the blue WF cap over time.

Earlier water scarcity studies either exclude the effect of reservoirs, or when they include it, they don't show the difference between water scarcity with and without reservoirs. Meigh et al. (1999), for example, estimated blue water scarcity for eastern and southern Africa with a distributed rainfall-runoff model incorporating reservoirs, but not explicitly showing their effect. Wada et al. (2011) assessed current monthly blue water scarcity at global scale using the PCR-GLOBWB model and Hanasaki et al. (2013) estimated future blue water scarcity under alternative climate scenarios based on the H08 model. Recent global studies that analyse runoff, water availability and water scarcity with and without dams include Haddeland et al. (2014) and Veldkamp et al. (2017), but these studies also consider the effect of water withdrawals, land use changes and climate change and do not present the effect of reservoirs separately. Until date there is no study that explicitly addresses the effect of reservoir storage on the redistribution of water availability and scarcity over time. Another gap left by earlier studies is that reservoir operations are usually simulated based on simple rules in hydrological models, which are calibrated based on observed downstream discharges rather than following real-time monitoring in reservoir storages (Wada et al., 2017).

The current study aims to investigate the role of reservoir storage in defining the blue WF cap in a river basin over time and in reducing blue water scarcity in a river basin during the months of relatively low water availability. This is done in a case study for the Yellow River Basin in China, making use of available observations in reservoir storage operations over the period from January 2002 to July 2006. This study provides information on how reservoir storage operations in practice affect the environmental health and the associated sustainability of human water consumption.

\section{Methods and data}

\subsection{Case study description}

The Yellow River Basin (YRB) is the second largest river basin of China, with a drainage area of $795 \times 10^{3} \mathrm{~km}^{2}$, feeding $9 \%$ of the national population, and contributing $13 \%$ of the national grain production, with only $2 \%$ of the national water resources (YRCC, 2013). According to previous studies, the YRB faces moderate to severe blue water scarcity during seven months a year (Hoekstra et al., 2012; Zhuo et al., 2016), but these studies don't include the redistributing effect of reservoirs on blue water availability. By the end of 2014, there were 29 large and 174 medium-sized reservoirs in the YRB (YRCC, 2015). The total storage capacity of all registered reservoirs was about $72 \times 10^{9} \mathrm{~m}^{3}$, which is equivalent to 1.2 times the mean annual natural runoff (Ran and $\mathrm{Lu}$, 2012). Almost all the large and medium reservoirs have been constructed in the upper and middle reaches of the basin (Ran and Lu, 2012). In the current study, we consider actual blue WFs, maximum sustainable blue WFs and blue water scarcity at basin and sub-reach level, on a monthly basis, by considering five large reservoirs: Longyangxia and Liujiaxia in the upper reach, and Wanjiazhai, Sanmenxia and Xiaolangdi in the middle reach (Table 1). All reservoirs are located on the river's main stream (Fig. 1). The total storage capacity 
Table 1

The five major reservoirs on the main stream of the Yellow River considered in this study.

\begin{tabular}{|c|c|c|c|c|c|}
\hline Reservoir & Longitude & Latitude & Storage capacity $\left(10^{9} \mathrm{~m}^{3}\right)$ & Area $\left(10^{6} \mathrm{~m}^{2}\right)$ & Year of completion \\
\hline Longyangxia & $100^{\circ} 54^{\prime} 57^{\prime \prime}$ & $36^{\circ} 7^{\prime} 15^{\prime \prime}$ & 27.6 & 353 & 1989 \\
\hline Liujiaxia & $101^{\circ} 48^{\prime} 26^{\prime \prime}$ & $36^{\circ} 7^{\prime} 3^{\prime \prime}$ & 5.7 & 113 & 1974 \\
\hline Wanjiazhai & $111^{\circ} 25^{\prime} 42^{\prime \prime}$ & $39^{\circ} 34^{\prime} 45^{\prime \prime}$ & 0.9 & 20 & 2000 \\
\hline Sanmenxia & $111^{\circ} 20^{\prime} 41^{\prime \prime}$ & $34^{\circ} 49^{\prime} 47^{\prime \prime}$ & 9.6 & 120 & 1961 \\
\hline Xiaolangdi & $112^{\circ} 21^{\prime} 37^{\prime \prime}$ & $34^{\circ} 55^{\prime} 26^{\prime \prime}$ & 12.7 & 263 & 2001 \\
\hline
\end{tabular}

of the considered reservoirs accounts for $78 \%$ of the total storage capacity of the basin's reservoirs. The study period, including a dry year (2002), a wet year (2003), and two average years (2004-2005), was chosen based on the availability of data on the storage changes for the considered reservoirs.

\subsection{Estimating the blue water footprint cap for a river basin over time}

The blue WF cap for a river basin in a specific month $\mathrm{m}\left(\mathrm{BWF}_{\mathrm{cap}, \mathrm{m}}\right)$, expressed in $\mathrm{m}^{3}$ per month, is defined as the natural runoff from the basin in that month $\left(R_{\text {nat, } m}\right)$ minus the environmental flow requirement $\left(\mathrm{EFR}_{\mathrm{m}}\right)$ (Hoekstra et al., 2011, 2012). With the inclusion of the effect of reservoir storage, monthly blue WF caps are estimated as:

$\mathrm{BWF}_{\text {cap }, \mathrm{m}}=\max \left(\mathrm{R}_{\mathrm{nat}, \mathrm{m}}-\sum_{\mathrm{i}=1}^{\mathrm{n}} \Delta \mathrm{S}_{\mathrm{i}, \mathrm{m}}-\mathrm{EFR}_{\mathrm{m}}, 0\right)$

where $\Delta \mathrm{S}_{\mathrm{i}, \mathrm{m}}$ refers to the change in storage of reservoir i in month $\mathrm{m}$, which equals to the storage at the end of the month minus the storage at the start of the month, and $n$ the total number of reservoirs considered. When $\Delta \mathrm{Si}_{\mathrm{m}}$ is positive, the reservoir storage increases over the month; when it is negative, the storage decreases. The equation shows how the cap on water consumption is raised when stored water is released, but also that the cap on water consumption in a specific month is lowered when water is stored (for later release and use). $\mathrm{EFR}_{\mathrm{m}}$ is estimated as a fraction of $R_{n a t, m}$. We assume here the presumptive EFR standard, i.e. $80 \%$ of $R_{\text {nat }}$ (Richter et al., 2012), as was also adopted in an earlier study for the YRB (Zhuo et al., 2016) as well as in a study for the Heihe River Basin in China (Zeng et al., 2012).

For a basin's sub-reach $\mathrm{x}$, the blue WF cap for that reach for a month $m\left(B W F_{\text {cap, } x, m}\right)$ equals the local natural runoff $\left(R_{\text {nat }, x, m}\right)$ minus the local environmental flow requirement $\left(\mathrm{EFR}_{\mathrm{x}, \mathrm{m}}\right)$ plus the blue water available from the upstream reach $\mathrm{x}-1\left(\mathrm{BWA}_{\mathrm{x}-1, \mathrm{~m}}\right)$ (Mekonnen and Hoekstra, 2016). $\mathrm{EFR}_{\mathrm{x}, \mathrm{m}}$ was estimated as $80 \%$ of $\mathrm{R}_{\mathrm{nat}, \mathrm{x}, \mathrm{m}}$ (Richter et al., 2012). With inclusion of the effect of reservoir storage in the river reach, $\mathrm{BWF}_{\mathrm{cap}, \mathrm{x}, \mathrm{m}}$ is estimated as:

$$
\mathrm{BWF}_{\mathrm{cap}, \mathrm{x}, \mathrm{m}}=\max \left(\mathrm{BWA}_{\mathrm{x}-1, \mathrm{~m}}+\mathrm{R}_{\mathrm{nat}, \mathrm{x}, \mathrm{m}}-\sum_{\mathrm{i}=1}^{\mathrm{n}_{\mathrm{x}}} \Delta \mathrm{S}_{\mathrm{i}, \mathrm{x}, \mathrm{m}}-\mathrm{EFR}_{\mathrm{x}, \mathrm{m}}, 0\right)
$$

BWA $_{\mathrm{x}-1, \mathrm{~m}}$ is estimated as the blue WF cap for the upstream reach $\left(\mathrm{BWF}_{\mathrm{cap}, \mathrm{x}-1, \mathrm{~m}}\right)$ minus the actual upstream blue water footprint $\left(B W F_{a c t, x-1, m}\right)$ :

$\mathrm{BWA}_{\mathrm{x}-1, \mathrm{~m}}=\max \left(\mathrm{BWF}_{\mathrm{cap}, \mathrm{x}-1, \mathrm{~m}}-\mathrm{BWF}_{\mathrm{act}, \mathrm{x}-1, \mathrm{~m}}, 0\right)$

\subsection{Estimating blue water scarcity over time}

The monthly blue water scarcity in a catchment is defined as the ratio of the total blue WF $\left(\mathrm{m}^{3}\right.$ month $\left.^{-1}\right)$ to its blue WF cap $\left(\mathrm{m}^{3}\right.$ month $\left.^{-1}\right)$ (Hoekstra et al., 2011). Blue water scarcity is classified



Fig. 1. Three reaches of the Yellow River Basin and the location of the five reservoirs considered in this study. Black stars refer to meteorological stations nearest to the reservoirs. 
into four levels (Hoekstra et al., 2012): 'low' when the blue WF is smaller than $20 \%$ of natural runoff; 'moderate' when the blue WF is between $20 \%$ and $30 \%$ of natural runoff; 'significant' when the blue WF is between $30 \%$ and $40 \%$ of natural runoff; and 'severe' when the blue WF exceeds $40 \%$ of natural runoff.

The total blue WF consists of the sum of the blue water consumption in the agricultural, industrial and municipal sectors as well as the blue water consumption of reservoirs. The monthly blue WF of a reservoir $\left(B W F_{r e s, m}\right)$ is equal to its total water surface evaporation over the month (Mekonnen and Hoekstra, 2012; Liu et al., 2015; Hogeboom et al., 2018):

$\mathrm{BWF}_{\text {res }, \mathrm{m}}=\mathrm{A}_{\text {res }, \mathrm{m}} \times \mathrm{E}_{\text {res }, \mathrm{m}} \times 10$

where $A_{\text {res,m }}\left(m^{2}\right)$ is the surface area of the reservoir, and $E_{r e s, m}(m m)$ the monthly evaporation.

\subsection{Data}

The data on observed monthly storage of each reservoir over the study period January 2002-July 2006 were provided by YRCC (2010). The monthly natural runoff of each reach of YRB over the study period was obtained from the hydrological model PCR-GLOBWB (Van Beek et al., 2011; Wada and Bierkens, 2014; Wada et al., 2011) at a spatial resolution of $6 \times 6$ arc $\min (\sim 9 \mathrm{~km} \times 11 \mathrm{~km}$ in the YRB). Data on measured daily evaporation by small evaporation pan at the nearest meteorological station of each reservoir (as shown in Fig. 1) over the study period were obtained from CMA (2016). We used a conversion coefficient of 0.62 (Sheng et al., 2007) to translate the observed evaporation to water surface evaporation. The estimated monthly blue WFs related to the agricultural, industrial and municipal sectors in the YRB over the study period (January 2002-July 2006) were taken from Zhuo et al. (2016).

\section{Results}

\subsection{The effect of reservoir storage on the blue WF cap for the YRB}

The annual natural runoff, reservoir storages at the start and the end of each year, changes in water storages, as well as the annual blue WF cap for the YRB without and with reservoir are listed in Table 2. The drier the year, the larger the effect of reservoir water releases in terms of raising the basin's annual blue WF cap. In the dry year 2002, the net storage release was equivalent to $16 \%$ of natural runoff, which led to a raise of the blue WF cap over the year by $79 \%$. In the wet year 2003 , however, a considerable amount of water was stored, a total equivalent to $12 \%$ of natural runoff, which lowered the blue WF cap over the year by $44 \%$ (from the level of $20 \%$ to $11 \%$ of natural runoff).

Fig. 2 shows the monthly blue WF cap for the YRB and three subreaches without and with reservoir storage, as well as the changes in storage for the period of January 2002 to July 2006. For the whole basin (Fig. 2a), in wet and average years, reservoirs reduced the blue WF cap during the flood season (July-October) and raised the blue WF cap in the period March-June, when blue water demand for irrigation is high (Zhuo et al., 2016). The peak for the blue WF cap with reservoir storage over a year was around June in most cases, one to three months earlier than the peak of natural runoff. In the dry year 2002, with limited natural runoff, the water release by reservoirs kept raising the blue WF cap in flood months. Over the study period, the monthly blue WF cap for the YRB with reservoirs varies from zero to $151 \%$ of natural runoff (the latter occurring in dry month of April 2004). The condition of zero blue WF cap happened in the wet year (February, August to October in 2003) and average years (March and September in 2004, and March, July to October in 2005), when the monthly net reservoir retention was larger than $20 \%$ of natural runoff and even reached 61\% of natural runoff in February 2003.

Across the three sub-reaches in the YRB, the effect of reservoir storage on blue WF caps differed distinctively (Fig. 2b-d), due to huge differences in the contribution of each reach to natural runoff and reservoir storage of the whole basin. On average, the upper, middle and lower reach account for $67 \%, 31 \%$ and $2 \%$ of YRB's annual natural runoff, respectively. As shown in Fig. 2b, the monthly blue WF cap for the upper reach (with the Longyangxia and Liujiaxia reservoirs) varies between zero and $196 \%$ of local natural runoff (with the highest value in the dry month of April 2006). Reservoirs generally increased storage during the rainy season (July-October), and released water during the rest of the year. In the dry year 2002, the net release of reservoirs was as much as $15 \%$ of natural runoff and raised the blue WF cap by $76 \%$. In the wet year 2003 and relatively wet average year 2005, the high reservoir retention in the wettest months (August-September 2003, JulyOctober 2005) led to zero blue WF caps for these months in the upper reach.

In the middle reach (Fig. 2c), in the case without reservoirs, there is a considerable blue water inflow from the upper reach mostly during July-December, which results in a relatively large monthly blue WF cap, equivalent to $21-64 \%$ of the natural runoff generated in the middle reach itself. In the case with reservoirs, the blue WF cap was substantially raised, as a result of net water releases from the reservoirs in both the upper and middle reach, over a large part of the dry year 2002, and in the periods of high irrigation water demands (April-July) in the other years as well. In 2002, the combined effect of reservoirs in the upper and lower reaches was that the overall blue WF cap over the year in the middle reach was raised by a factor 2.7. In the considered years, reservoirs generally stored water from July to November and the water release in the rest months made the peak of blue WF cap shift to May, four months earlier than that without reservoirs.

Given the low local natural runoff of the lower reach, and the absence of major reservoirs, water availability in this reach depends on inflow of water generated in the upper and middle reaches and on the operation of the upstream reservoirs (Fig. 2d). Without reservoirs, the blue water availability is largest from August to October. The upstream reservoirs cause the annual blue WF cap for the lower reach to raise significantly (by a factor of 5) in the dry year 2002. In both the dry year and the average years, the upstream reservoirs make the peak in the monthly blue WF cap in the lower reach shift from August-October to June and/or July, with a second peak in October-December. In the wet year 2003, the huge amount of water storage by reservoirs in the middle reach substantially reduced the blue water flowing to the lower reach in

Table 2

Yearly reservoir storage changes and annual blue water footprint cap for the Yellow River Basin without and with reservoir storage (period: 2002-2005).

\begin{tabular}{|c|c|c|c|c|c|c|c|c|c|c|c|}
\hline \multirow[t]{2}{*}{ Year } & \multirow{2}{*}{$\begin{array}{l}\text { Natural } \\
\text { runoff }\left(10^{9}\right. \\
\left.\mathrm{m}^{3}\right)\end{array}$} & \multirow[t]{2}{*}{$\begin{array}{l}\text { Water storage at the start } \\
\text { of the year }\left(10^{9} \mathrm{~m}^{3}\right)\end{array}$} & \multirow[t]{2}{*}{$\begin{array}{l}\text { Water storage at the end } \\
\text { of the year }\left(10^{9} \mathrm{~m}^{3}\right)\end{array}$} & \multicolumn{6}{|c|}{ Changes in storage $\left(10^{9} \mathrm{~m}^{3}\right)$} & \multicolumn{2}{|c|}{$\begin{array}{l}\text { Blue water footprint } \\
\text { cap }\left(10^{9} \mathrm{~m}^{3}\right)\end{array}$} \\
\hline & & & & $\begin{array}{l}\text { Longyangxia } \\
\text { (Upper } \\
\text { reach) }\end{array}$ & $\begin{array}{l}\text { Liujiaxia } \\
\text { (Upper } \\
\text { reach) }\end{array}$ & $\begin{array}{l}\text { Wanjiazhai } \\
\text { (Middle } \\
\text { reach) }\end{array}$ & $\begin{array}{l}\text { Sanmenxia } \\
\text { (Middle } \\
\text { reach) }\end{array}$ & $\begin{array}{l}\text { Xiaolangdi } \\
\text { (Middle } \\
\text { reach) }\end{array}$ & Total & $\begin{array}{l}\text { Without } \\
\text { reservoir }\end{array}$ & $\begin{array}{l}\text { With } \\
\text { reservoir }\end{array}$ \\
\hline 2002 & 43.2 & 19.5 & 12.7 & -3.83 & -0.83 & 0.00 & -0.04 & -2.16 & -6.86 & 8.6 & 15.5 \\
\hline 2003 & 95.4 & 12.7 & 25.2 & 6.23 & 0.44 & 0.07 & 0.29 & 5.50 & 12.5 & 19.1 & 10.7 \\
\hline 2004 & 71.7 & 25.2 & 23.5 & 1.10 & -0.20 & -0.16 & -0.02 & -1.74 & -1.02 & 14.3 & 17.6 \\
\hline 2005 & 81.8 & 23.5 & 34.3 & 10.2 & -0.12 & -0.06 & -0.12 & 1.22 & 11.1 & 16.4 & 11.9 \\
\hline
\end{tabular}


(a) Whole basin

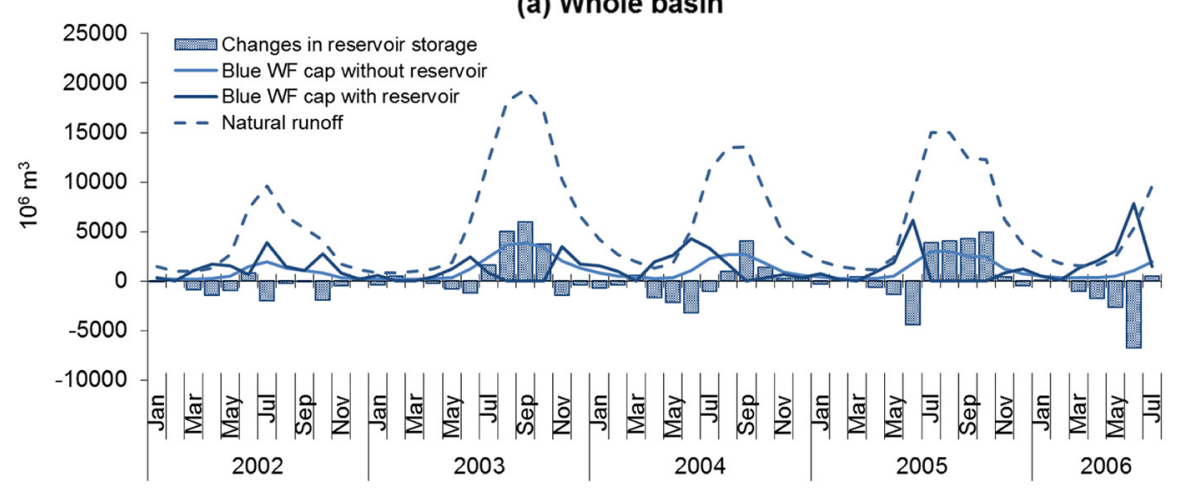

(b) Upper Reach

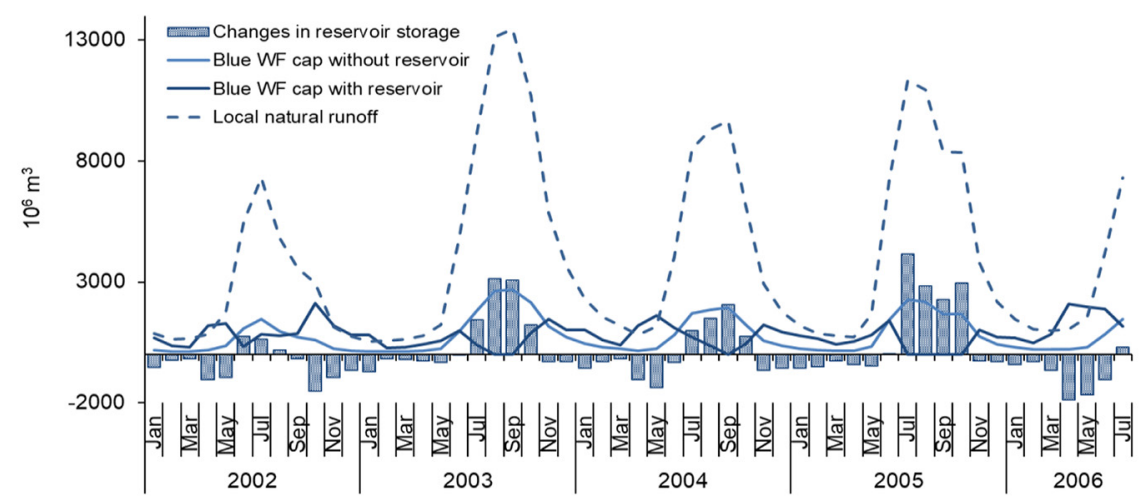

(c) Middle Reach

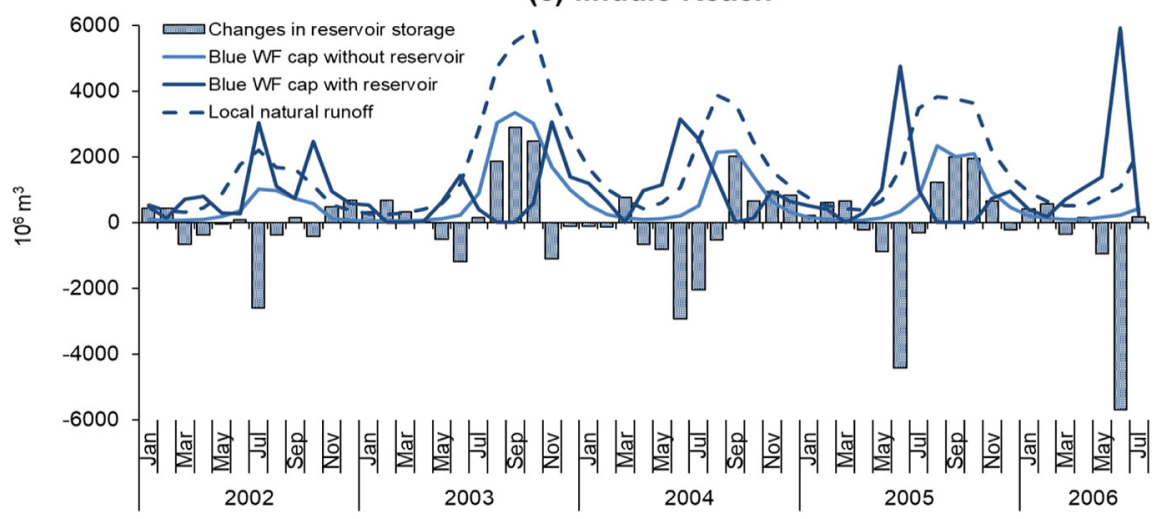

(d) Lower Reach

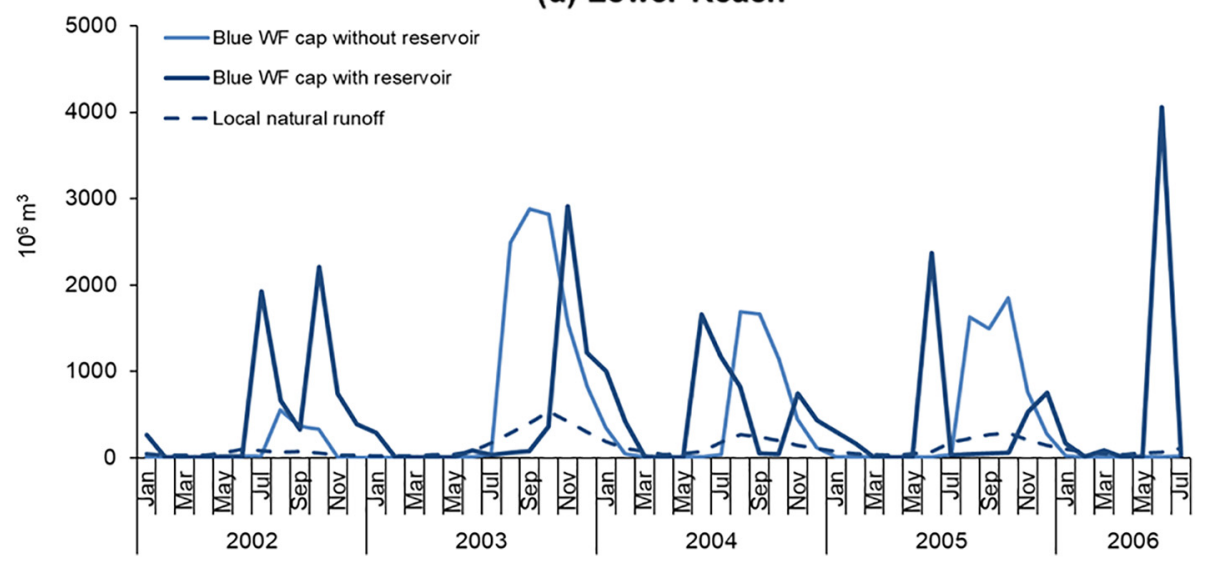

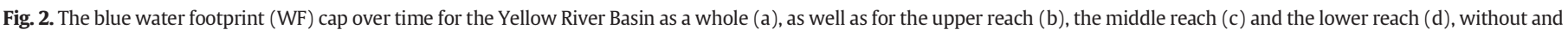
with reservoirs. Period: January 2002-July 2006. 
the period July to October and the annual blue WF cap for the lower reach was halved.

A finding that is counterintuitive at first sight is that, with reservoirs, blue WF caps become small and sometimes zero in the wet period of the year, particularly in the wet years. The reason is that water retention in the reservoirs often exceeds $20 \%$ of natural runoff in the wet months in the wet years. Since environmental flow requirements are taken as $80 \%$ of the natural flow (following Richter et al., 2012), there is no flow left for consumptive use by humans in these months.

\subsection{The effect of reservoir storage on blue water scarcity in the YRB}

Blue water scarcity is indicated by the ratio of blue WF to blue WF cap. Here the blue WF includes water consumption by all agriculture, industries and municipalities in the basin as well as evaporation from the five reservoirs considered. The average annual total blue $\mathrm{WF}$ in the YRB over the period 2002-2005 was $20 \times 10^{9} \mathrm{~m}^{3} \mathrm{y}^{-1}$. The annual blue WF of reservoirs accounted for $3 \%\left(\sim 666 \times 10^{6} \mathrm{~m}^{3} \mathrm{y}^{-1}\right)$ of the total annual blue WF in the YRB as an average over the study period. Among the five considered reservoirs, Longyangxia reservoir had the largest annual blue WF $\left(305 \times 10^{6} \mathrm{~m}^{3} \mathrm{y}^{-1}\right.$ averaged over 2002-2005), followed by Xiaolangdi reservoir $\left(178 \times 10^{6} \mathrm{~m}^{3} \mathrm{y}^{-1}\right)$ and Liujiaxia reservoir $\left(104 \times 10^{6} \mathrm{~m}^{3} \mathrm{y}^{-1}\right)$.

Table 3 shows the annual blue water scarcity of the YRB and the number of months that the basin faces low, moderate, significant and severe blue water scarcity, without and with reservoirs, at both basin and sub-reach level. The reservoirs strongly reduce blue water scarcity in a dry year (2002), but increase blue water scarcity in a wet year (2003). In 2002, the number of months with severe water scarcity in the basin as a whole decreased from 5 to 3 months by the presence of the reservoirs. In 2003, the number of months with severe water scarcity in the basin as a whole increased from 6 to 8 months by the presence of the reservoirs. This may be surprising at first sight, but can better be understood by explicitly comparing monthly blue WFs to monthly blue WF caps over time as is done in Fig. 3.

Fig. 3 compares, for each month in the study period, the blue WF to the blue WF cap, in the YRB as a whole as well as per sub-reach, for both the case without and the case with reservoirs. The figures show that reservoir storage operations redistribute not only the blue WF cap, but also the level of blue water scarcity over months. The reservoirs shift the peaks of blue WF caps to match the peaks of blue WFs. However, the results also indicate that water retention by reservoirs in the flood season is often so large that environmental high-flow requirements are no longer met, resulting in severe blue water scarcity even in the rainy period. The results thus show how reservoirs contribute to "scarcity in the wet months", which is to be understood as a situation in which environmental flow requirements related to the occurrence of natural peak flows are no longer met. Natural runoff is high in the wet months, but environmental flow requirements in these months are high as well (to maintain peak flows on which various ecological processes depend), and when very substantial fractions of the natural flow are retained in reservoirs, there is no water left for human consumption if environmental flows are to be maintained.

The five large reservoirs considered serve multiple purposes, not only water supply in the dry period, but also hydroelectricity generation, flood control and ice prevention. Since 2002, the three reservoirs in the middle reach also have the task of sediment flushing (Baoligao et al., 2016), which is generally done between late June and mid-July, by releasing clear water from the reservoirs to scour downstream (YRCC, 2005). As a result, the blue WF cap for June in the middle and lower reaches were much higher than the blue WF, as shown in Fig. 2c-d.

\subsection{Discussion}

The current study provides a method of assessing monthly blue WF caps and blue water scarcity for a river basin taking large reservoirs into consideration and using the observed reservoir storage records. The main difference in the introduced blue WF cap estimation method (Eqs. (1) and (2)) from the existing methods (Mekonnen and Hoekstra, 2016; Veldkamp et al., 2017) is the separate variable of the reservoir storage changes $(\Delta S)$. The algorithm enables the comparison between the blue WF caps with and without reservoirs, i.e. showing the effects of reservoir operation on the blue WF cap as well as the

Table 3

Annual blue water scarcity in the Yellow River Basin and the number of months the basin faces low, moderate, significant and severe blue water scarcity. Period: $2002-2005$.

\begin{tabular}{|c|c|c|c|c|c|c|c|c|c|c|}
\hline \multirow[t]{3}{*}{ Year } & \multicolumn{2}{|c|}{ Annual blue water scarcity* } & \multicolumn{8}{|c|}{ Number of months per year with low, moderate, significant and severe water scarcity } \\
\hline & \multirow[t]{2}{*}{ Without reservoir } & \multirow[t]{2}{*}{ With reservoir } & \multicolumn{4}{|c|}{ Without reservoir } & \multicolumn{4}{|c|}{ With reservoir } \\
\hline & & & Low & Moderate & Significant & Severe & Low & Moderate & Significant & Severe \\
\hline \multicolumn{11}{|c|}{ Whole basin } \\
\hline 2002 & 1.99 & 1.11 & 3 & 2 & 2 & 5 & 5 & 3 & 1 & 3 \\
\hline 2003 & 0.98 & 1.75 & 5 & 1 & 0 & 6 & 2 & 2 & 0 & 8 \\
\hline 2004 & 1.42 & 1.16 & 7 & 1 & 0 & 4 & 4 & 4 & 1 & 3 \\
\hline 2005 & 1.46 & 2.01 & 5 & 2 & 1 & 4 & 4 & 0 & 0 & 8 \\
\hline Average & 1.33 & 1.44 & 5 & 2 & 1 & 4 & 4 & 1 & 4 & 3 \\
\hline \multicolumn{11}{|c|}{ Upper reach } \\
\hline 2002 & 1.17 & 0.66 & 5 & 2 & 2 & 3 & 9 & 1 & 1 & 1 \\
\hline 2003 & 0.60 & 1.09 & 6 & 0 & 1 & 5 & 4 & 1 & 4 & 3 \\
\hline 2004 & 1.01 & 1.04 & 7 & 1 & 0 & 4 & 7 & 2 & 0 & 3 \\
\hline 2005 & 0.96 & 1.73 & 6 & 1 & 1 & 4 & 4 & 1 & 1 & 6 \\
\hline Average & 0.85 & 1.06 & 6 & 2 & 0 & 4 & 5 & 3 & 1 & 3 \\
\hline \multicolumn{11}{|c|}{ Middle reach } \\
\hline 2002 & 1.86 & 0.70 & 3 & 1 & 2 & 6 & 7 & 1 & 2 & 2 \\
\hline 2003 & 0.67 & 1.13 & 5 & 0 & 1 & 6 & 5 & 0 & 0 & 7 \\
\hline 2004 & 1.04 & 0.70 & 7 & 0 & 0 & 5 & 7 & 2 & 0 & 3 \\
\hline 2005 & 1.17 & 1.15 & 5 & 1 & 0 & 6 & 5 & 0 & 2 & 5 \\
\hline Average & 1.00 & 0.88 & 5 & 1 & 2 & 4 & 8 & 0 & 1 & 3 \\
\hline \multicolumn{11}{|c|}{ Lower reach } \\
\hline 2002 & 1.43 & 0.29 & 3 & 0 & 0 & 9 & 7 & 0 & 0 & 5 \\
\hline 2003 & 0.17 & 0.36 & 5 & 0 & 0 & 7 & 4 & 1 & 0 & 7 \\
\hline 2004 & 0.27 & 0.23 & 7 & 0 & 0 & 5 & 7 & 0 & 0 & 5 \\
\hline 2005 & 0.29 & 0.41 & 5 & 1 & 0 & 6 & 5 & 0 & 1 & 6 \\
\hline Average & 0.30 & 0.31 & 6 & 0 & 1 & 5 & 8 & 0 & 1 & 3 \\
\hline
\end{tabular}




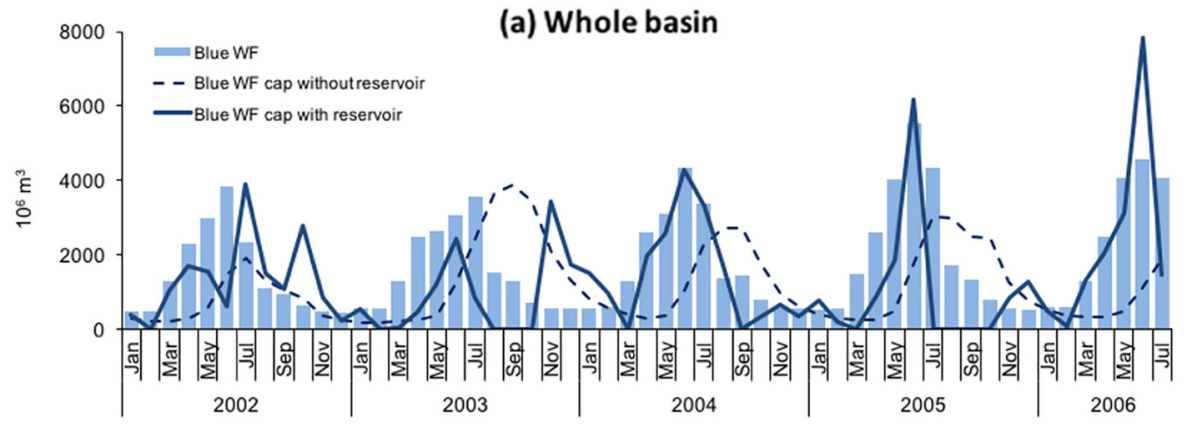

(b) Upper Reach
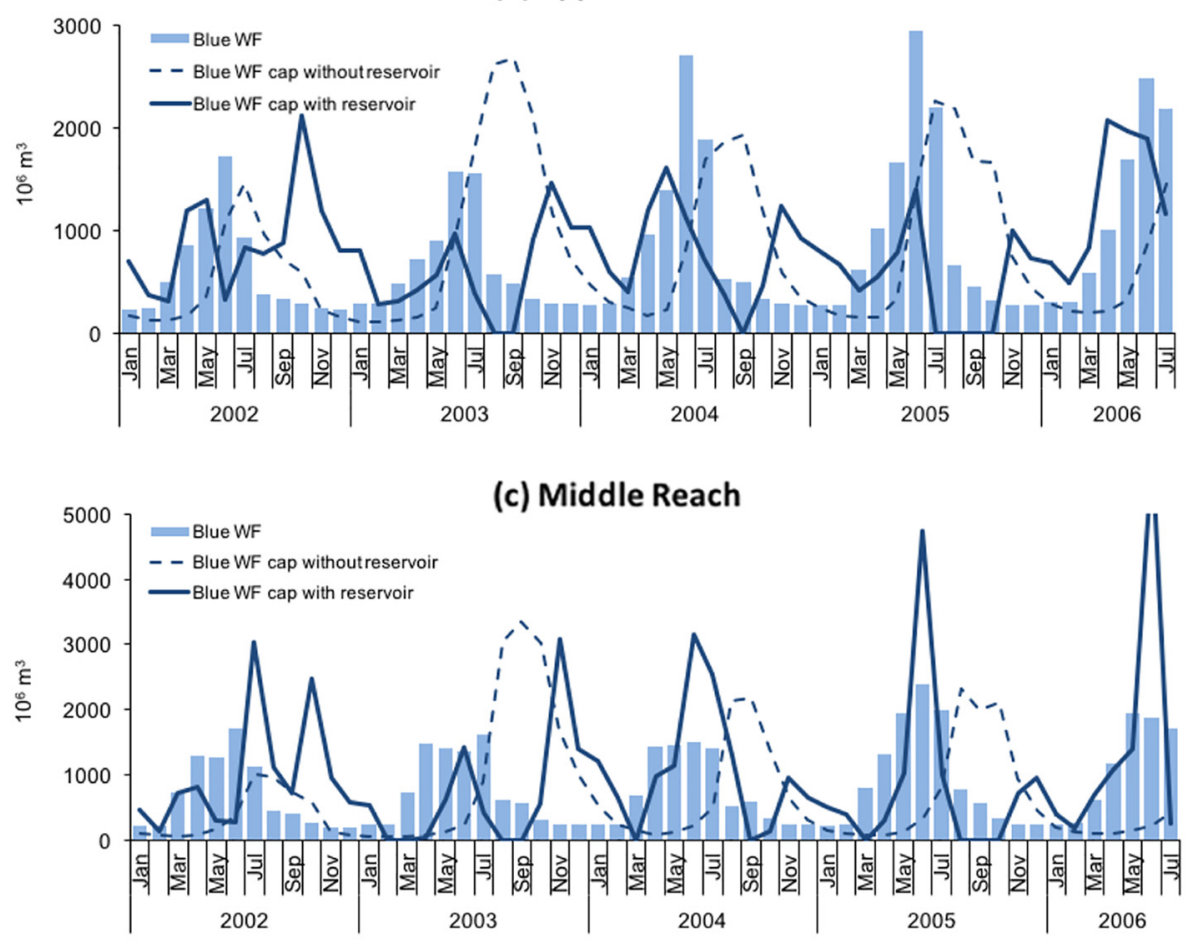

(d) Lower Reach

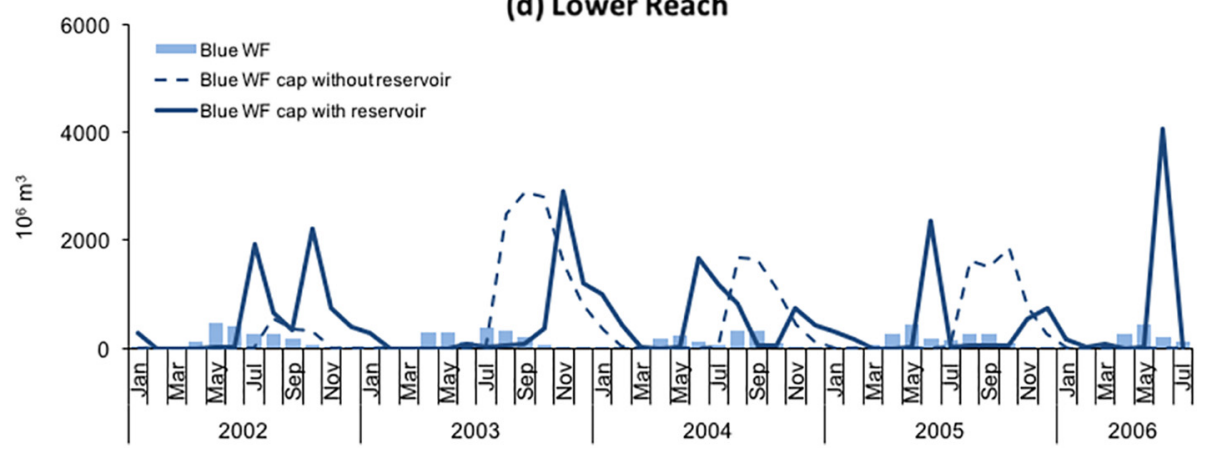

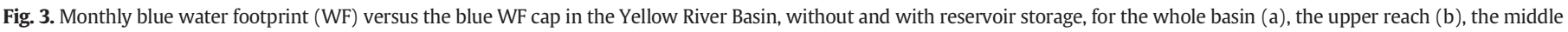
reach (c) and the lower reach (d). Period: January 2002-July 2006.

resulting blue water scarcity levels. The inclusion in the current study period of dry, medium and wet years helps to see the carry-over effect of reservoirs across years. In practice, the reservoir operations are for the purpose of meeting hydropower requirements as well as water supply needs for downstream users, and based on inflows and the available storage in reservoirs (GAQSIQ 1998). Since hydroelectric generation needs smoothing of runoff just like the purpose of water supply, the effect of both functions on changing WF caps and water scarcity over the year is similar.
The current study was carried out with the historical data on monthly reservoir storage changes. For applications of the introduced method in reservoir operation planning, one can best use hydrological models with an embedded reservoir operation scheme (e.g. Hanasaki et al., 2006). Combined with a monthly blue water scarcity assessment and consideration of environmental flow requirements, water managers can then identify the reservoir operation plans that benefit both water users and environmental health downstream. 
Table 4

Comparison of results on annual blue water footprint of reservoir with previous studies.

\begin{tabular}{|c|c|c|c|c|c|c|}
\hline \multirow[t]{2}{*}{ Study } & \multirow[t]{2}{*}{ Study period } & \multicolumn{5}{|c|}{ Annual blue WF of reservoir $\left(10^{6} \mathrm{~m}^{3} \mathrm{y}^{-1}\right)$} \\
\hline & & Longyangxia & Liujiaxia & Wanjiazhai & Sanmenxia & Xiaolangdi \\
\hline Tian et al. (2005) & 1972-1998 & 265 & 60 & & 103.8 & \\
\hline Liu et al. (2015) & 2010 & 313 & 116 & 25 & 306 & 96 \\
\hline Current study & 2002-2005 & 305 & 104 & 16 & 64 & 178 \\
\hline
\end{tabular}

Compared to previous blue water scarcity studies at river basin level (Zhuo et al., 2016; Hoekstra et al., 2012; Zeng et al., 2012), we included the evaporation losses from reservoirs in the estimation of the total blue WF in the YRB. In Table 4 we compare our estimates of the blue WF of reservoirs with two earlier studies (Tian et al., 2005; Liu et al., 2015). Given the differences in periods considered, we cannot really compare the estimates, but our results are of the same order of magnitude as the previous estimates. Marked differences in the blue WF for Sanmenxia and Xiaolangdi with Liu et al. (2015) as well as for Liujiaxia with Tian et al. (2005) were due to differences in the corresponding reservoir area records.

A limitation of the study is that we consider only five large reservoirs along the main stream of the Yellow River. The considered reservoirs account for $78 \%$ of basin's total reservoir capacity, which is a substantial part of the whole, but the other reservoirs in the YRB are mostly medium and small reservoirs, which may have relatively smaller or larger impacts on river flows and water scarcity mitigation. Furthermore, the study is limited to an analysis of five years only, due to the limited availability of observed time series for reservoir storages. Long-term observations ( $>30$ years) are necessary to get a more complete picture of the effect of reservoirs on environmental flows and water scarcity.

WF estimates contain uncertainties as propagated form uncertainties in the models and data used (Mekonnen and Hoekstra, 2011). For the YRB, the uncertainty range in WF records for crop production due to input uncertainties has been estimated to be in a range of \pm 30\% from the average (Zhuo et al., 2014). Van Beek et al. (2011) showed that the performance of the PCR-GWBWB model regarding monthly runoff simulations for the YRB was acceptable, with a slope of 0.74 and $r^{2}$ of 0.64 . Nevertheless, this shows that obtaining better estimates of water footprints and water availability can still significantly alter the results, albeit not the general conclusions drawn in this study. We adopted the precautious standard for environmental flow requirements (EFR) as proposed by Richter et al. (2012), which defines EFR as a constant fraction of $80 \%$ of monthly natural runoff, and that has been used in various earlier blue WF and scarcity studies (Hoekstra et al., 2012; Zeng et al., 2012; Mekonnen and Hoekstra, 2016; Zhuo et al., 2016). This assumption affects the estimation of monthly blue WF caps and monthly water scarcity levels. There are numerous other proposals for simple rules to establish EFRs, like the ones from Pastor et al. (2014), Yang et al. (2009) and Smakhtin et al. (2004), who have generally assumed EFRs at lower percentages (37-60\%) of natural runoff. We tested the sensitivities of the YRB's annual blue WF caps and the estimated number of months with severe blue water scarcity to changes in (1) the basin's annual blue WF by $\pm 30 \%$, (2) annual natural runoff by $\pm 30 \%$, and (3) the standard for environmental flow requirements. Although the blue WF caps move up or down with less or more strict standards regarding the water flows to be reserved for nature, the type of effects that reservoirs have on estimated water scarcity levels over time are the same: reduced scarcity levels in dry years and dry periods of the year and increased scarcity levels in wet years and wet periods of the year.

\section{Conclusions}

We demonstrate what effects reservoirs can have on the maximum sustainable water consumption and water scarcity levels in a basin within and across years. Reservoirs do not increase the total volume of water available for consumption - they even reduce volume due to the evaporation from the reservoirs as we show - but they redistribute water availability within the year and between years, in order to better match the demands over time. While water demands are often countercyclical to water availability - certainly in the YRB - reservoirs retain water in the wet periods when demands are low and release water in the dry periods when demands are high. This is all to be expected and our results confirm this quantitatively. With a net storage release equivalent to $16 \%$ of natural runoff in the dry year 2002 , the blue WF cap in that year was raised by $79 \%$. With a net storage increase of $12 \%$ of natural runoff in the wet year 2003, the blue WF cap was lowered by $44 \%$. Surprising, because counterintuitive, is the finding that reservoirs increase water scarcity as well, namely in the wet periods of the year and particularly in the relatively wet years. The number of months suffering severe blue water scarcity increased from 6 without reservoirs to 8 (including the flood season over July to October) with reservoirs in the wet year 2003. This relates to the fact that much water is retained in reservoirs during wet times, as a result of which high-flow environmental flow requirements are no longer met. In this study we demonstrate that the water scarcity metric as proposed by Hoekstra et al. (2011) is able to capture not only scarcity as a result of a mismatch between water consumption and water availability, but also the effects of reservoirs on both the water consumption side and the water availability side. On the consumption side, reservoirs contribute the blue water consumption because of the evaporation from the reservoirs. On the availability side, reservoirs will always both decrease scarcity by replenishing water supply (in months that water is released) and increase scarcity by withholding water (in months that water is retained). The study shows that formulating blue WF caps is instrumental to an understanding of how much water is available for human consumption over the year and that reservoirs affect the distribution of runoff and thus WF caps within and over years.

\section{Acknowledgments}

The work was partially developed within the framework of the Panta Rhei Research Initiative of the international Association of Hydrological Sciences (IAHS). We thank Dr. Yoshihide Wada for providing data on natural runoff. This work was supported by the Chinese Academy of Sciences [XAB2017B03], Northwest A \& F University [2452017010] and the Fundamental Research Funds for the Central Universities [2452017181], and Department of Human Resources and Social Security of Shaanxi Province [2017034].

\section{References}

Bakken, T.H., Kjosavik, F., Killingtveit, Å., Alfredsen, K., 2015. Are reservoirs water consumers or water collectors? Reflections on the water footprint concept applied on reservoirs. Water Resour. Manag. 29 (4), 4919-4926.

Baoligao, B., Xu, F., Chen, X., Wang, X., Chen, W., 2016. Acute impacts of reservoir sediment flushing on fishes in the Yellow River. J. Hydro Environ. Res. 13, 26-35. https://doi.org/10.1016/j.jher.2015.11.003.

Biemans, H., Haddeland, I., Kabat, P., Ludwig, F., Hutjes, R.W.A., Heinke, J., Von Bloh, W. Gerten, D., 2011. Impact of reservoirs on river discharge and irrigation water supply during the 20th century. Water Resour. Res. 47, W03509. https://doi.org/10.1029/ 2009WR008929.

Brauman, K.A., Richter, B.D., Postel, S., Malsy, M., Flörke, M., 2016. Water depletion: an improved metric for incorporating seasonal and dry-year water scarcity into water risk assessments. Elementa 4, 000083. https://doi.org/10.12952/journal. elementa.000083. 
CMA, 2016. China Meteorological Data Sharing Service System. China Meteorological Administration, Beijing, China Available at. http://data.cma.cn.

Degefu, D.M., Weijun, H., Zaiyi, L., Liang, Y., Zhengwei, H., Min, A., 2018. Mapping monthly water scarcity in global transboundary basins at country-basin mesh based spatial resolution. Sci. Rep. 8, 2144. https://doi.org/10.1038/s41598-018-20032-w.

Döll, P., Fiedler, K., Zhang, J., 2009. Global-scale analysis of river flow alterations due to water withdrawals and reservoirs. Hydrol. Earth Syst. Sci. 13, 2413-2432.

GAOSIO 1998. Specification of reservoir operation for large and medium scale hydropower stations (GB17621-1998, National Standard). General Administration of Quality Supervision, Inspection and Quarantine of the PR China. Beijing, China.

Haddeland, I., Skaugen, T., Lettenmaier, D.P., 2006. Anthropogenic impacts on continenta surface water fluxes. Geophys. Res. Lett. 33, L08406. https://doi.org/10.1029/ 2006GL026047.

Haddeland, I., Heinke, J., Biemans, H., Eisner, S., Flörke, M., Hanasaki, N., Konzmann, M. Ludwig, F., Masaki, Y., Schewe, J., Stacke, T., Tessler, Z.D., Wada, Y., Wisser, D., 2014 Global water resources affected by human interventions and climate change. Proc. Natl. Acad. Sci. U. S. A. 111 (9), 3251-3256. https://doi.org/10.1073/ pnas. 1222475110

Hanasaki, N., Kanae, S., Oki, T., 2006. A reservoir operation scheme for global river routing models. J. Hydrol. 327, 22-41. https://doi.org/10.1016/j.jhydrol.2005.11.011.

Hanasaki, N., Fujimori, S., Yamamoto, T., Yoshikawa, S., Masaki, Y., Hijioka, Y., Kainuma, M., Kanamori, Y., Masui, T., Takahashi, K., Kanae, S., 2013. A global water scarcity assessment under shared socio-economic pathways - part 2: water availability and scarcity. Hydrol. Earth Syst. Sci. 17, 2393-2413. https://doi.org/10.5194/hess-172393-2013.

Hoekstra, A.Y., 2013a. The Water Footprint of Modern Consumer Society. Routledge, London, U.K.

Hoekstra, A.Y., 2013b. Sustainable, efficient, and equitable water use: the three pillars under wise freshwater allocation. WIREs Water 1 (1), 31-40. https://doi.org/ 10.1002/wat2.1000

Hoekstra, A.Y., Chapagain, A.K., Aldaya, M.M., Mekonnen, M.M., 2011. The Water Footprint Assessment Manual: Setting the Global Standard. 2011. Earthscan, London, UK.

Hoekstra, A.Y., Mekonnen, M.M., Chapagain, A.K., Mathews, R.E., Richter, B.D., 2012 Global monthly water scarcity: blue water footprints versus blue water availability. PLoS One 7 (2), e32688. https://doi.org/10.1371/journal.pone.0032688.

Hogeboom, R.J., Knook, L., Hoekstra, A.Y., 2018. The blue water footprint of the world's artificial reservoirs for hydroelectricity, irrigation, residential and industrial water supply, flood protection, fishing and recreation. Adv. Water Resour. 113, 285-294.

Jaramillo, F., Destouni, G., 2015. Local flow regulation and irrigation raise global human water consumption and footprint. Science 350, 6265.

Liu, J., Zhao, D., Gerbens-Leenes, P.W., Guan, D., 2015. China's rising hydropower demand challenges water sector. Sci. Rep. 5, 11446. https://doi.org/10.1038/srep11446.

Meigh, J.R., McKenzie, A.A., Sene, K.J., 1999. A grid-based approach to water scarcity estimates for eastern and Southern Africa. Water Resour. Manag. 13, 85-115.

Mekonnen, M.M., Hoekstra, A.Y., 2011. The green, blue and grey water footprint of crops and derived crop products. Hydrol. Earth Syst. Sci. 15 (5), 1577-1600.

Mekonnen, M.M., Hoekstra, A.Y., 2012. The blue water footprint of electricity from hydropower. Hydrol. Earth Syst. Sci. 16 (1), 179-187.

Mekonnen, M.M., Hoekstra, A.Y., 2016. Four billion people facing severe water scarcity. Sci. Adv. 2 (2), e1500323. https://doi.org/10.1126/sciadv.1500323.

Mekonnen, M.M., Pahlow, M., Aldaya, M.M., Zarate, E., Hoekstra, A.Y., 2015. Sustainability, efficiency and equitability of water consumption and pollution in Latin America and the Caribbean. Sustain. For. 7, 2086-2112. https://doi.org/10.3390/su7022086.

Nilsson, C., Reidy, C.A., Dynesius, M., Revenga, C., 2005. Fragmentation and flow regulation of the world's large river systems. Science 308,5720 .

Oki, T., Kanae, S., 2006. Global hydrological cycles and world water resources. Science 313 1068

Pahlow, M., Snowball, J., Fraser, G., 2015. Water footprint assessment to inform water management and policy making in South Africa. Water SA 41 (3), 300-313. https:// doi.org/10.4314/wsa.v41i2.02.

Pastor, A.V., Ludwig, F., Biemans, H., Hoff, H., Kabat, P., 2014. Accounting for environmental flow requirements in global water assessments. Hydrol. Earth Syst. Sci. 18, 5041-5059. https://doi.org/10.5194/hess-18-5041-2014.

Postel, S.L., Daily, G.C., Ehrlich, P.R., 1996. Human appropriation of renewable fresh water. Science 271, 5250

Ran, L., Lu, X.X., 2012. Delineation of reservoirs using remote sensing and their storage estimate: an example of the Yellow River basin, China. Hydrol. Process. 26, 1215-1229. https://doi.org/10.1002/hyp.8224.
Richter, B.D., Davis, M., Apse, C., Konrad, C., 2012. A presumptive standard for environmental flow protection. River Res. Appl. 28, 1312-1321.

Schyns, J.F., Hoekstra, A.Y., 2014. The added value of water footprint assessment for National Water Policy: a case study for Morocco. PLoS One 9 (6), e99705. https://doi. org/10.1371/journal.pone.0099705.

Sheng, Q., Shen, S., Gu, Z., 2007. Conversion coefficient between small evaporation pan and theoretically calculated water surface evaporation in China. J. Nanjing Inst. Meteorol. 30 (4), 561-565.

Smakhtin, V., Revenga, C., Döll, P., 2004. A pilot global assessment of environmental water requirements and scarcity. Water Int. 29, 307-317. https://doi.org/10.1080/ 02508060408691785

Tian, J.H., Cui, Q., Xu, J.H., Zhou, X., 2005. Surface-evaporation of large and middle reservoirs affects the count of water resource in the Yellow River Valley. J. Shandong Agric. Univ. Nat. Sci. 36 (3), 391-394.

Van Beek, L., Wada, Y., Bierkens, M.F.P., 2011. Global monthly water stress: 1. Water balance and water availability. Water Resour. Res. 47, W07517. https://doi.org/10.1029/ 2010WR009791.

Veldkamp, T.I.E., Wada, Y., Aerts, J.C.J.H., Döll, P., Gosling, S.N., Liu, J., Masaki, Y., Oki, T., Ostberg, S., Pokhrel, Y., Satoh, Y., Kim, H., Ward, P.J., 2017. Water scarcity hotspots travel downstream due to human interventions in the 20th and 21st century. Nat. Commun. 8, 15697. https://doi.org/10.1038/ncomms15697.

Vörösmarty, C.J., Sharma, K., Fekete, B., Copeland, A.H., Holden, J., Marble, J., Lough, J.A., 1997. The storage and aging of continental runoff in large reservoir systems of the world. Ambio 26, 210-219.

Wada, Y., Bierkens, M.F.P., 2014. Sustainability of global water use: past reconstruction and future projections. Environ. Res. Lett. 9, 104003. https://doi.org/10.1088/17489326/9/10/104003.

Wada, Y., Van Beek, L., Viviroli, D., Dürr, H.H., Weingartner, R., Bierkens, M.F.P., 2011. Global monthly water stress: 2 . Water demand and severity of water stress. Water Resour. Res. 47, W07518. https://doi.org/10.1029/2010WR009792.

Wada, Y., Bierkens, M.F.P., de Roo, A., Dirmeyer, P.A., Famiglietti, J.S., Hanasaki, N., Konar, M., Liu, J., Müller Schmied, H., Oki, T., Pokhrel, Y., Sivapalan, M., Troy, T.J., van Dijk, A.I.J.M., van Emmerik, T., Van Huijgevoort, M.H.J., Van Lanen, H.A.J., Vörösmarty, C.J., Wanders, N., Wheater, H., 2017. Human-water interface in hydrological modeling: current status and future directions. Hydrol. Earth Syst. Sci. Discuss. https://doi.org/ 10.5194/hess-2017-248 (in review).

Yang, Z.F., Sun, T., Cui, B.S., Chen, B., Chen, G.Q., 2009. Environmental flow requirements for integrated water resources allocation in the Yellow River Basin, China. Commun. Nonlinear Sci. Numer. Simul. 14, 2469-2481. https://doi.org/10.1016/j. cnsns.2007.12.015.

Yoshikawa, S., Cho, J., Yamada, H.G., Hanasaki, N., Kanae, S., 2014. An assessment of global net irrigation water requirements from various water supply sources to sustain irrigation: rivers and reservoirs (1960-2050). Hydrol. Earth Syst. Sci. 18, 4289-4310. https://doi.org/10.5194/hess-18-4289-2014.

YRCC, 2005. Yellow River water resources bulletin 2004. Yellow River Conservancy Commission, Zhengzhou, China.

YRCC, 2010. Hydro dataset of key hydrologic stations and reservoirs in the Yellow River Basin. Yellow River Conservancy Commission, Available at: The Ecological Environment Database of Loess Plateau (www.loess.csdb.cn) by Institute of Soil and Water Conservation of Chinese Academy of Science.

YRCC, 2013. Comprehensive Planning of the Yellow River Basin for 2012-2030. Yellow River Conservancy Commission, Zhengzhou, China.

YRCC, 2015. Yellow River Water Resources Bulletin 2014. Yellow River Conservancy Commission, Zhengzhou, China.

Zeng, Z., Liu, J., Koeneman, P.H., Zarate, E., Hoekstra, A.Y., 2012. Assessing water footprint at river basin level: a case study for the Heihe River Basin in northwest China. Hydrol. Earth Syst. Sci. 16, 2771-2781. https://doi.org/10.5194/hess-16-2771-2012.

Zhuo, L., Mekonnen, M., Hoekstra, A., 2014. Sensitivity and uncertainty in crop water footprint accounting: a case study for the Yellow River Basin. Hydrol. Earth Syst. Sci. 18 (6), 2219-2234

Zhuo, L., Mekonnen, M.M., Hoekstra, A.Y. Wada, Y., 2016. Inter- and intra-annual variation of water footprint of crops and blue water scarcity in the Yellow River Basin (1961-2009). Adv. Water Resour. 87, 21-41. https://doi.org/10.1016/j. advwatres.2015.11.002. 